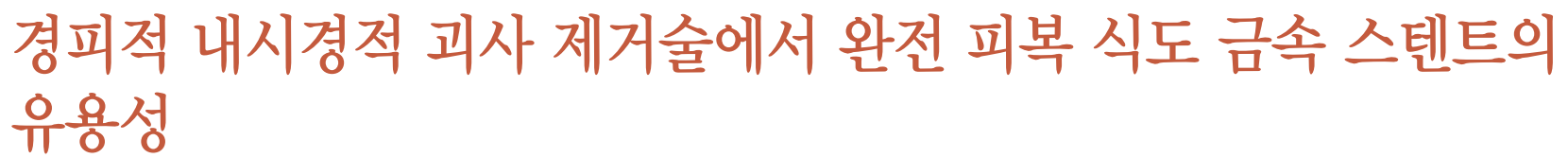

울산대학교 의과대학 서울아산병원 내과

이나겸 · 박도현 · 박신희 · 박수연 · 정수민 · 오진선 · 서보미

\title{
Utility of Fully Covered Esophageal Metal Stent in Percutaneous Endoscopic Necrosectomy
}

\author{
Nah Kyum Lee, Do Hyun Park, Shinhee Park, Suyeon Park, Soomin Jeung, Jin Sun Oh, Bomi Seo \\ Department of Internal Medicine, University of Ulsan College of Medicine, Asan Medical Center, Seoul, Korea
}

\begin{abstract}
Necrotizing pancreatitis is associated with high rates of morbidity and mortality. Managing necrotizing pancreatitis is challenging, and minimally invasive treatment modalities recently replaced traditional open necrosectomy. Percutaneous catheter drainage and endoscopic necrosectomy are now widely used because they are less invasive, safer, and can more effectively remove necrotic materials. Various methods and novel techniques have been introduced to manage walled-off necrosis. Herein, we report a case series of patients with necrotizing pancreatitis who were successfully treated using fully covered esophageal metal stent and endoscopic necrosectomy via the percutaneous approach. Percutaneous endoscopic necrosectomy using a fully covered esophageal stent is an effective endoscopic treatment for patients with walled-off necrosis that extends along both sides of the paracolic gutter, reduces the number of necrosectomy sessions, and improves disease status faster than conventional treatment.
\end{abstract}

Korean J Pancreatobiliary 2015;20(2):88-93

Keywords: Pancreatitis, Stent , Necrosis, Cholangiopancreatography, Endoscopic retrograde

\author{
Received Jan. 2, 2015 \\ Revised Feb. 26, 2015 \\ Accepted Mar. 5, 2015
}

Corresponding author: Do Hyun Park Division of Gastroenterology, Department of Internal Medicine, Asan Medical Center, 88 Olympic-ro 43-gil, Songpa-gu, Seoul 138-736, Korea

Tel. +82-2-3010-3194 Fax. +82-2-476-0824 E-mail; dhpark@amc.seoul.kr

This is an Open Access article distributed under the terms of the Creative Commons Attribution Non-Commercial License (http:// creativecommons.org/licenses/by-nc/3.0/) which permits unrestricted non-commercial use, distribution, and reproduction in any medium, provided the original work is properly cited.

Copyright $\odot 2015$ by The Korean Journal of Pancreas and Biliary Tract

\section{서 론}

급성 췌장염은 담석, 음주, 약물, 복부 외상, 고중성지방혈 증 및 고칼슘혈증과 같은 대사장애, 감염 등의 다양한 원인 에 의해 췌장선 세포의 손상이 발생하고 광범위한 간질성 부 종이 발생하는 췌장의 염증성 질환이다. 급성 췌장염의 $80 \%$ 에서는 경한 임상양상을 보이고 보존적인 치료로 대부분 호 전되지만, $20 \%$ 는 괴사성 췌장염으로 진행하게 된다. 괴사성
췌장염은 사망률이 $15 \%$ 에 이르고 $20-35 \%$ 에서 감염이 동반 될 수 있으며 감염이 동반될 경우 패혈증과 다발성 장기 부 전이 발생하여 사망률이 더욱 증가하게 된다. ${ }^{1}$ 따라서 임상 양상과 진단 검사 및 영상 검사를 통한 정확한 진단과 적절 한 치료가 필요하다. 고전적으로 괴사성 췌장염의 치료로 수 술적 괴사 제거술이 많이 시행되었으나 최근에는 경피적 배 액술과 내시경적 괴사 제거술을 포함한 최소침습적 시술이 괴사성 췌장염 치료에 널리 이용되고 있다. 경피적 배액술과 
내시경적 괴사 제거술과 같은 치료법은 기존의 수술적 괴사 제거술과 비교하여 덜 침습적이고 더욱 안전하며 효율적으 로 괴사성 췌장염을 치료할 수 있다. ${ }^{2}$ 저자들은 괴사성 췌장 염 환자에서 완전 피복 식도 금속 스텐트(fully covered esophageal metal stent)를 이용하여 경피적 내시경적 괴사 제 거술로 대장 주변(paracolic gutter)으로 연장된 막으로 둘러 싸인 괴사(walled-off necrosis)를 성공적으로 치료한 사례들 을 경험하였기에 문헌 고찰과 함께 보고하는 바이다.

\section{증 례}

\section{증례 1}

52 세 여자 환자가 복통과 황달을 주소로 응급실에 내원하 였다. 환자는 내원 6개월 전 운전자 교통사고로 복부 둔상을 입었고 당시 시행한 복부 전산화 단층촬영 (computerized tomography)과 내시경 역행 담췌관 조영술(endoscopic retrograde cholangiopancreatography) 결과 American Association for the Surgery of Trauma에서 제시하는 췌장 외상 분 류에 따라 췌장의 타박상이 있으나 췌관 손상이 없는 췌장 손상 grade II 소견을 보였다. 환자는 응급실 내원 전 췌장 외 상에 의한 괴사성 췌장염으로 4 개의 경피적 배액관을 가지 고 있었다. 응급실 내원 당시 급성 병색을 보였으며 말초 혈 액 검사에서 백혈구 $13,400 / \mathrm{mm}^{3}$, 혈색소 $7.3 \mathrm{~g} / \mathrm{dL}$, 혈소판
$83,000 / \mathrm{mm}^{3}$, amylase $28 \mathrm{U} / \mathrm{L}$, lipase $56 \mathrm{U} / \mathrm{L}$, aspartate aminotransferase $26 \mathrm{IU} / \mathrm{L}$, alanine aminotransferase $11 \mathrm{IU} / \mathrm{L}$, alkaline phosphatase $168 \mathrm{IU} / \mathrm{L}$ 로 확인되었고 total bilirubin $5.8 \mathrm{mg} / \mathrm{dL}$, direct bilirubin $4.2 \mathrm{mg} / \mathrm{dL}$, C-reactive protein이 $21.84 \mathrm{mg} / \mathrm{dL}$ 로 증가되었다. 내시경 초음파 검사(endoscopic ultrasound)에서 췌장의 몸통에 막으로 둘러싸인 췌장 괴사 (walled-off pancreas necrosis)가 관찰되었고 복부 전산화 단 층촬영에서 막으로 둘러싸인 괴사가 우측 대장 주변(paracolic gutter)으로 연장되어 있는 소견을 보였다(Fig. 1A). 경 피적 배액관을 통하여 배액된 액체를 배양한 결과 carbapenem-resistant Acinetobacter baumannii, carbapenem-resistant Enterobacteriaceae, methicillin-resistant Staphylococcus aureus 가 동정되었고 항균제 감수성 결과에 따라 적절한 항생제를 투여하였다. 경피적 배액술 및 적절한 항생제 사용 에도 불구하고 임상 경과 호전 보이지 않아 입원 15 일째 경 피적 배액관 도관 삽입 자리에 형성된 누공을 통하여 완전 피복 식도 금속 스텐트(직경 $18 \mathrm{~mm}$, 길이 $12 \mathrm{~cm}$; Taewoong Medical, Seoul, South Korea)를 삽입하였다. 이후 CRE 풍선 (Boston Scientific, Natick, Mass)을 사용하여 식도 금속 스 텐트가 충분히 확장될 수 있도록 하였고 직경 $5.5 \mathrm{~mm}$ 의 비 강 내시경(GIF-XP260N, Olympus)을 사용하여 경피적 내시 경적 괴사 제거술을 시행하였다(Fig. 1B). 2일 간격으로 총 3 차례의 경피적 내시경적 괴사 제거술로 다량의 조직 파편
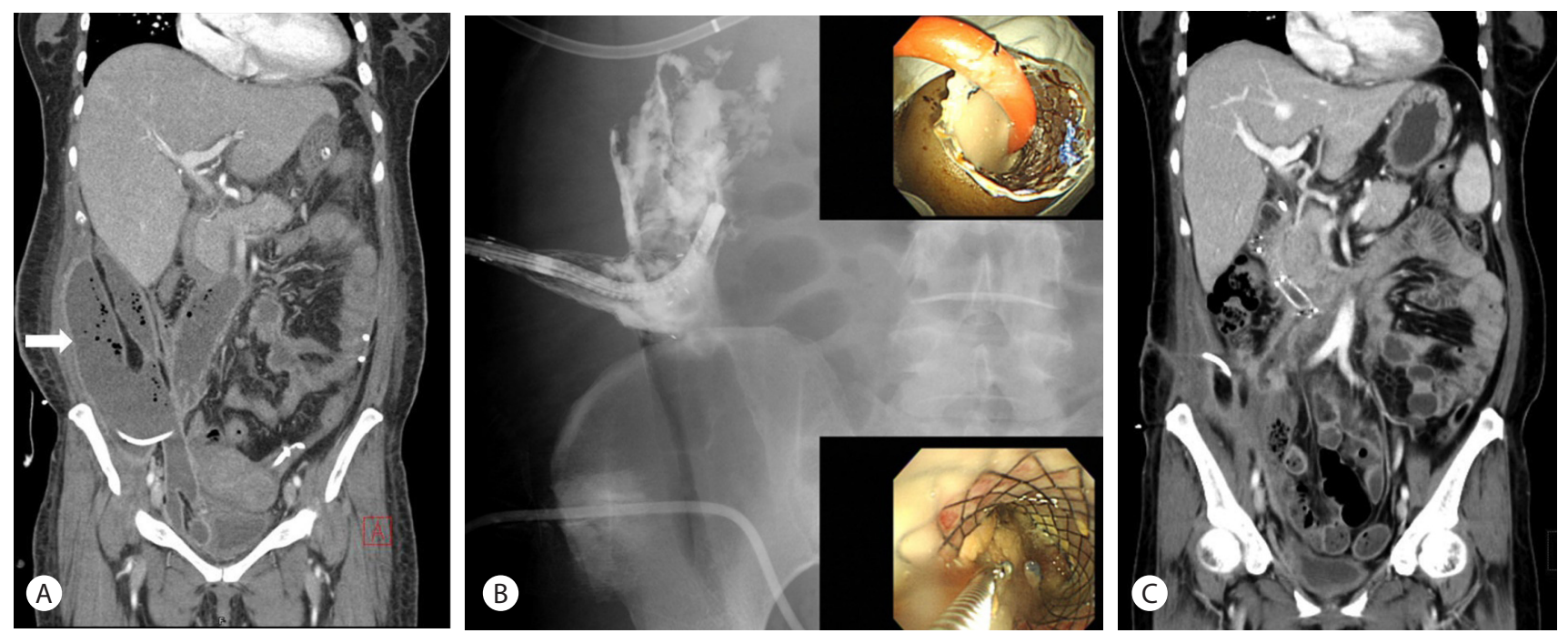

Fig. 1. Case 1. (A) Coronal CT scan of the abdomen and pelvis. On admission, CT scan showed large amount of collected fluid in the right paracolic gutter with air bubbles inside. (B) (Upper inset) The placement of a fully covered esophageal metal stent via percutaneous tract. (Lower inset) Endoscopic necrosectomy was performed through the esophageal stent via percutaneous approach. (C) After the third percutaneous endoscopic necrosectomy using esophageal stent, decreased fluid collection and interval improvement in walled-off necrosis were seen. 
(necrotic debris)을 제거하였고 3번째 괴사 제거술에서 조직 파편의 현격한 감소를 확인한 후 식도 금속 스텐트를 제거하 였다. 3 차례의 시술 후 검사한 복부 전산화 단층촬영에서 췌 장 주위에서 대장 주변까지 연장된 막으로 둘러싸인 괴사는 현저하게 감소되었다(Fig. 1C). 이후 발열과 복통이 호전되
었고 검사실 소견상 C-reactive protein이 감소하고 total bilirubin이 정상화되어 퇴원하였다.

\section{증례 2}

39세 남자 환자가 심와부 통증을 주소로 내원하였다. 평소
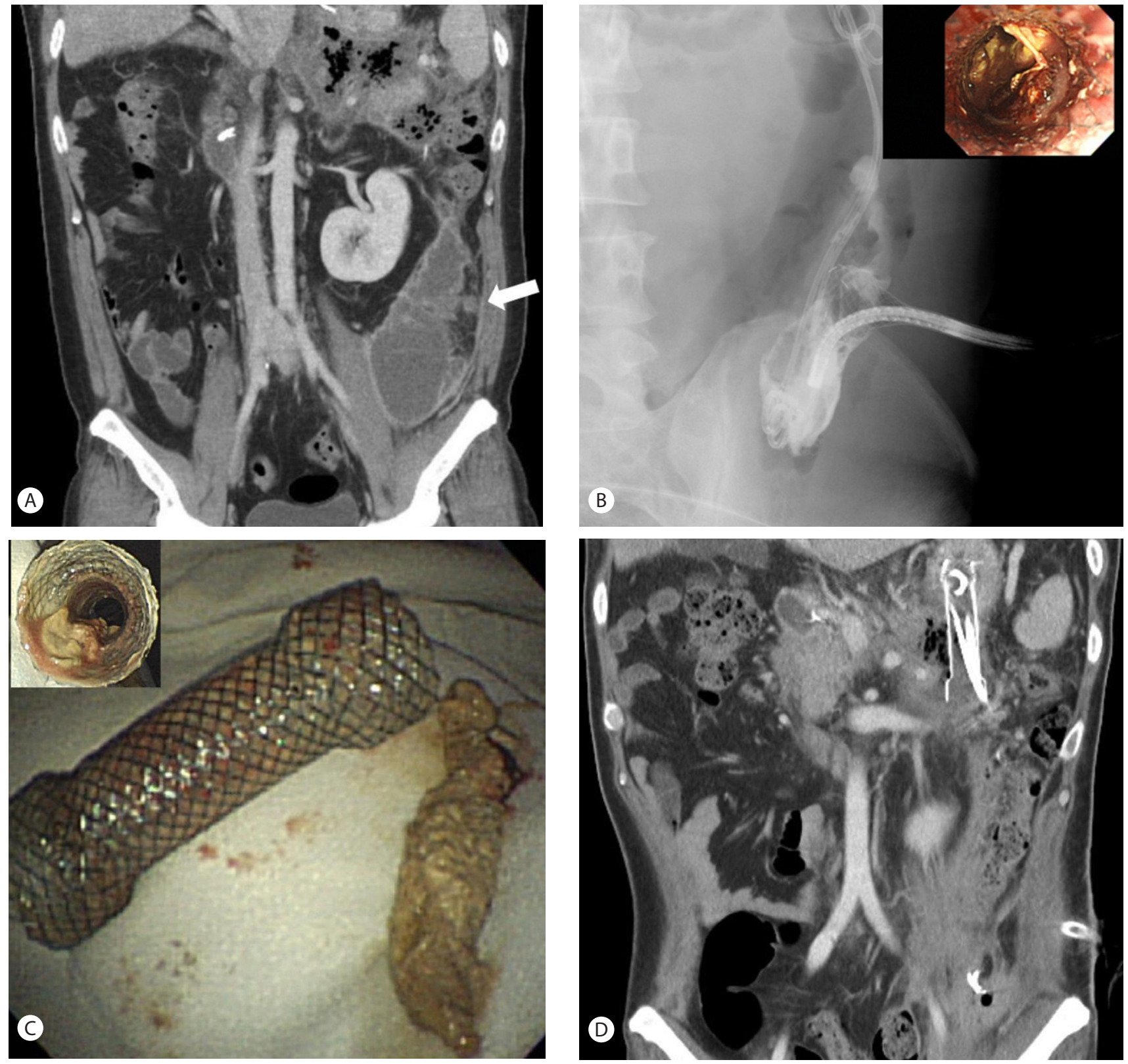

Fig. 2. Case 2. (A) CT scan was performed at the second admission, which shows air-containing walled-off necrosis involving the pancreas tail and left paracolic gutter. (B) Left flank lesion where the esophageal stent was inserted. Endoscopic necrosectomy was performed through the esophageal stent. Necrotic debris was seen through the stent. (C) A fully covered esophageal metal stent which was used in case 2 patient. Necrotic debris was seen inside the esophageal stent. (diameter $20 \mathrm{~mm}$, length $6 \mathrm{~cm}$; Taewoong Medical, Seoul, South Korea) (D) CT scan was performed after the second percutaneous endoscopic necrosectomy, decreased fluid collection and interval improvement in walled-off necrosis were seen. Endoscopic transluminal drainage with fully covered metal stent and a $5 \mathrm{Fr}$ endoscopic nasobiliary drainage (ENBD) catheter are also seen on CT scan. 
음주를 자주 하던 분으로 내원 당시 체온이 $38.3^{\circ} \mathrm{C}$ 로 확인되 었고 황달을 보였다. 말초 혈액 검사에서 백혈구 증가증 및 C-reactive protein 상승이 확인되었고 혈청 amylase와 lipase 가 정상 범위의 10 배 이상 상승되어 있었다. 복부 전산화 단 층촬영에서 췌장의 부종과 췌장 주위의 액체 고임, 담낭의 부종이 관찰되었고 담석 췌장염으로 판단하여 내시경 역행 담췌관 조영술을 시행하였다. 내시경 역행 담췌관 조영술을 통하여 담즙 슬러지를 제거하였고 2개의 플라스틱 스텐트를 삽입하였다. 이후 통증 조절, 항생제 투약을 포함한 보존적 치료 후 임상 경과 호전되어 퇴원하였다. 퇴원 2주 후 복통으 로 다시 입원하였고 복부 전산화 단층촬영에서 췌장 꼬리와 왼쪽 후복막 공간에 막으로 둘러싸인 괴사가 관찰되었다 (Fig. 2A).

내시경 초음파에서 췌장 꼬리에 $6 \mathrm{~cm}$ 크기의 막으로 둘러 싸인 췌장 괴사가 관찰되었고 배액을 원활하게 하기 위해 2 개의 스텐트를 삽입하여 경벽적 배액술(transmural drainage)을 시행하였다. 5 일 후 $39^{\circ} \mathrm{C}$ 의 발열이 발생하여 추적한 복부 전산화 단층촬영에서 이전보다는 감소되었으나 여전 히 췌장 꼬리와 왼쪽 후복막 공간에 공기를 포함한 액체 고 임이 관찰되었고 완전 피복 금속 스텐트를 삽입하여 내시경 적 배액술(endoscopic transluminal drainage)을 시행하였으 며 두 개의 이중 돼지꼬리형 요도 카테터를 좌측 신장 주변 공간에 삽입하였다. 이후 임상 경과가 호전되어 퇴원하였다. 두 번째 퇴원한 지 2주 후 발열로 재입원하였고 복부 전산화 단층촬영에서 이전보다는 감소하였으나 여전히 막으로 둘 러싸인 괴사가 관찰되었고 경피적 배액술과 4 회의 내시경적 괴사 제거술을 시행하였으나 임상 경과 호전 없어 경피적 배 액관을 제거하고 완전 피복 식도 금속 스텐트(직경 $20 \mathrm{~mm}$, 길이 $6 \mathrm{~cm}$; Taewoong Medical, Seoul, South Korea)를 왼쪽 대장 주변부(paracolic gutter)에 삽입하였다. 이후 CRE 풍선 (Boston Scientific, Natick, Mass)을 사용하여 식도 금속 스 텐트가 충분히 확장될 수 있도록 하였고 직경 $5.5 \mathrm{~mm}$ 의 비 강 내시경(GIF-XP260N, Olympus)을 사용하여 경피적 내시 경적 괴사 제거술을 시행하였으며 다량의 조직파편이 제거 되었다(Fig. 2B). 2일 후 두 번째 경피적 내시경적 괴사 제거 술이 시행되었고 시술 후 조직 파편이 현저하게 감소한 것을 확인하였으며 식도 금속 스텐트는 시술 종료와 함께 제거되 었다(Fig. 2C). 7 일 후 추적한 복부 전산화 단층촬영 결과 왼 쪽 대장 주변부(paracolic gutter)와 췌장 주변의 막으로 둘러 싸인 괴사는 현저하게 감소하였다(Fig. 2D).

\section{고 찰}

급성 췌장염 환자의 $80 \%$ 는 경한 임상양상을 보이고 통증 조절, 수액 및 영양 공급, 췌장염 유발 요인에 대한 치료를 시 행할 경우 수일 내 호전된다. 그러나 $20 \%$ 의 환자에서는 췌 장의 괴사가 발생하게 되고 이는 높은 이환율 및 사망률과 연관되어 있는 것으로 알려져 있다. ${ }^{1}$ 괴사성 췌장염은 췌장 실질의 괴사가 동반되는 염증성 질환으로 새로 개정된 2012 급성 췌장염 Atlanta 분류에 따르면 괴사성 췌장염은 질환의 발병 시점에 따라 발병한 지 4 주 이내이고 분명한 막이 없는 급성 괴사성 고임(acute necrotic collection)과 발병한 지 4주 이후이고 분명한 막이 형성된 막으로 둘러싸인 괴사로 나뉘 어 진다. ${ }^{3}$ 괴사성 췌장염 환자에서 보존적 치료를 하면서 내 시경 시술 또는 수술적 치료는 정상 췌장 조직과 괴사된 췌 장 조직 사이의 경계가 명확해지는 췌장염 발생 4-6주 후에 시행하는 것이 권고되고 있고 이는 시술 중 출혈과 같은 합 병증을 감소시키고 불필요한 정상 췌장 조직의 절제를 감소 시키는 것과 연관되어 있다. ${ }^{4}$ 괴사성 췌장염 환자의 주된 사 망 원인은 췌장 감염과 동반된 패혈증과 다발성 장기 부전이 다. ${ }^{5}$ 감염은 췌장 실질 괴사와 인접한 부위에 있는 위장관계 로부터 세균의 전파에 의해서 발생하는 것으로 알려져 있고 감염을 일으키는 흔한 균에는 Escherichia coli, Staphylococcus aureus, Enterococcus faecalis 등이 있다. ${ }^{6}$ 감염은 질병의 기간 중 어느 때나 발생할 수 있으나 보통 질병이 발생한 지 2-4주 사이에 가장 흔하게 발생하고 일반적인 항생제 치료에 도 불구하고 임상적으로 악화를 보이는 경우 내시경 초음파 유도하에 췌장 및 췌장 주위 액체 고임을 세침 흡인하여 그 람 염색 및 세균 배양으로 췌장 감염을 진단할 수 있다. ${ }^{7}$ 감염 성 괴사의 경우 즉시 항생제를 투여하고 감염 부위의 배액이 나 내시경 및 수술적 치료와 같은 중재적 시술이 필요하다. 수술적 괴사 제거술은 전통적으로 중증의 급성 췌장염 환자 에서 치료의 표준으로 여겨졌다. 하지만 수술적 괴사 제거술 은 수술에 따르는 사망률이 높고 입원 기간이 길며, 수술 부 위 감염, 탈장, 출혈, 장누공 등의 합병증이 발생할 수 있을 뿐만 아니라 전신 염증 반응 증후군(systemic inflammatory response syndrome)을 악화시켜 다발성 장기 부전에 이르는 경우가 종종 발생하게 된다. ${ }^{8}$ 현재 괴사성 췌장염은 경피적 배액술, 내시경적 괴사 제거술 또는 비디오 후복막강 변연 절제술(video-assisted retroperitoneal debridement)과 같은 최소 침습 시술을 이용하여 치료하는 것이 보편적으로 받아 
들여지고 있고 ${ }^{2,9}$ 막으로 둘러싸인 괴사와 췌장 주위 액체 고 임(peripancreatic fluid collection)을 치료하는 다양한 방법 들이 소개되고 있다. 내시경적 배액술을 사용한 예로, Attam 등 $^{10}$ 은 $10 \mathrm{~cm}$ 이상 크기의 막으로 둘러싸인 괴사가 있는 10 명의 환자에서 대구경 완전 피복 식도 금속 스텐트(large bore, fully covered esophageal stent)를 사용하여 내시경적 배액술 (endoscopic transluminal drainage)을 시행하여 막으로 둘러 싸인 괴사를 치료한 사례를 보고하였다. 또한 Varadarajulu 등 $^{11}$ 은 막으로 둘러싸인 췌장 괴사와 위장관계 사이에 내시 경 초음파를 통해 2-3개의 경벽관(transmural tract)을 생성 하여 다수의 스텐트를 사용한 경벽적 배액술(transmural drainage)과 하나의 경벽관을 통한 경벽적 배액술로 췌장 괴 사를 치료한 사례를 비교한 연구 결과를 보고하였다. 막으로 둘러싸인 췌장 괴사가 있는 60 명의 환자 중 12 명에서 2-3개 의 다수의 경벽관을 통하여 내시경적 배액이 시행되었고 48 명에서 하나의 경벽관을 통하여 내시경적 배액이 시행되었 으며 다수의 경벽관을 통한 내시경적 배액술의 경우 $91.7 \%$ 의 치료 성공률을 나타내었고 하나의 경벽관을 통한 내시경 적 배액술은 $52.1 \%$ 의 치료 성공률을 보여주어 다수의 경벽 관을 통한 내시경적 배액술의 유용성에 대해 보고하였다. ${ }^{11}$ 하지만 골반강이나 대장 주변과 같이 내시경이 접근하기 어 려운 위치에 액체 고임이나 막으로 둘러싸인 괴사가 있을 경 우 내시경적 배액술만으로 임상 경과의 호전을 기대하기는 어렵다. 경피적 배액술은 내시경이 접근하기 어려운 위치에 액체 고임이 위치해 있거나 액체 고임의 막이 덜 성숙되어 있을 때 유용하게 사용될 수 있으며, 최근에는 경피적 배액 술과 내시경적 괴사 제거술의 유용성을 접목하여 경피적 내 시경적 괴사 제거술을 시행하여 감염성 췌장 괴사를 치료한 사례가 여러 기관에서 보고되고 있다. Dhingra 등리 ${ }^{12}$ 이 165 명 의 환자를 대상으로 수행한 연구에 따르면, 103 명의 괴사성 췌장염 환자들 중 74 명에서 감염성 췌장 괴사가 발생하였고 이 중 15 명에서 경피적 내시경적 괴사 제거술이 시행되었다. Dhingra 등 ${ }^{12}$ 은 감염성 췌장 괴사가 있는 복강에 $16 \mathrm{~F}-18 \mathrm{~F}$ 의 튜브를 경피적으로 삽입하였고 2-3일 후 CRE 풍선을 사용하 여 관(tract)을 확장한 이후 튜브를 통한 내시경적 괴사 제거 술을 시행하였다. 평균 5 회의 시술이 시행되었고 14 명의 환 자가 추가적인 시술 없이 퇴원하였다. Kedia 등 ${ }^{13}$ 은 완전 피 복 식도 금속 스텐트를 사용하여 경피적 내시경적 괴사 제거 술로 후복막강에 위치한 액체 고임을 치료한 사례를 보고하 였고 국내에서도 배액관 도관 삽관 자리를 통한 경피적 내시
경적 괴사 제거술을 시행한 1 예가 보고된 바가 있으나 ${ }^{14}$ 현재 까지 본 증례와 같이 완전 피복 식도 금속 스텐트를 사용하 여 경피적 내시경적 괴사 제거술을 시행한 예는 국내에서 보 고된 바가 없다.

식도 금속 스텐트는 일반적으로 식도암으로 인한 식도 협 착에 주로 사용하고 스텐트의 팽창력이 크며 유연성이 우수 하다. 본 증례에서는 식도 금속 스텐트의 팽창력과 유연성을 이용하였고 식도 금속 스텐트를 사용할 경우 기존의 경피적 배액술에 사용하는 카테터나 담도 스텐트와 비교할 때 직경 이 더 크기 때문에 다량의 조직파편이 쉽고 빠르게 제거될 수 있어 피부로 삽입된 스텐트를 조기에 제거할 수 있다. 증 례 1 의 환자에서는 2 일 간격으로 총 3 회의 경피적 내시경적 괴사 제거술을 시행한 후 식도 금속 스텐트를 제거하였고 증 례 2 의 환자에서는 2 일 간격으로 총 2 회의 경피적 내시경적 괴사 제거술을 시행한 후 식도 금속 스텐트를 제거할 수 있 었다. 결과적으로 증례 1 의 환자는 6 일, 증례 2 의 환자는 2 일 동안 식도 금속 스텐트를 유지하였고 스텐트를 경피적으로 삽입 및 제거하는 과정에서 기술적으로 어려운 점은 없었다. 또한 내시경이 식도 금속 스텐트를 쉽게 통과할 수 있어 내 시경 의사가 용이하게 내시경적 괴사 제거술을 시행할 수 있 다. 기존의 연구에서 사용한 $16 \mathrm{~F}-18 \mathrm{~F}$ 의 튜브를 사용할 경우 수일 간격으로 $\mathrm{CRE}$ 풍선을 사용한 관의 단계적 확장이 필요 하나 식도 금속 스텐트를 사용할 경우 CRE 풍선을 사용한 스텐트 팽창이 쉽게 이루어져 삽입과 동시에 내시경적 괴사 제거술을 시행할 수 있고 다량의 조직파편 제거를 통하여 괴 사 제거술의 시행 횟수와 시술 시간이 감소하게 된다.

결론적으로 완전 피복 식도 금속 스텐트를 사용한 경피적 내시경적 괴사 제거술은 기존의 내시경적 괴사 제거술이나 경피적 배액술보다 내시경 시행 횟수와 시술 시간이 감소하 고 더욱 효율적이고 빠르게 막으로 둘러싸인 괴사를 치료할 수 있다. 첫 번째 증례에서는 우측 복강에 식도 금속 스텐트 를 삽입하여 우측 대장 주변으로 연장된 막으로 둘러싸인 괴 사를 경피적 내시경적 괴사 제거술로 치료하였고 두 번째 증 례에서는 좌측 복강에 식도 금속 스텐트를 삽입하여 막으로 둘러싸인 괴사를 치료하였으며 시술 후 출혈, 누공, 탈장 등 의 합병증이 발생하지 않았다. 본 증례는 기존의 경피적 또 는 내시경적 배액술을 일차적으로 시행하였음에도 불구하 고 임상적인 호전을 보이지 않는 괴사성 췌장염 환자에서 직 경이 큰 완전 피복 식도 금속 스텐트를 사용하여 경피적 내 시경적 괴사 제거술로 대장 주변으로 연장된 막으로 둘러싸 
인 괴사를 치료한 예로 내시경이 접근하기 어려운 위치에 액 체 고임이나 막으로 둘러싸인 괴사가 있는 괴사성 췌장염 환 자에게서 효율적인 치료 방법의 하나로 사용될 수 있을 것이 다. 기존에 사용하던 플라스틱 튜브와 비교하여 직경이 큰 완전 피복 금속 스텐트(fully covered metal stent)가 팽창성 및 유연성을 고려할 때 경피적 내시경적 괴사 제거술에 유용 하게 사용될 수 있고 앞으로 금속 스텐트를 사용한 경피적 내시경적 괴사 제거술에 대한 다기관 연구를 통하여 시술 적 응증과 치료 성공률, 주요 합병증에 대한 추가적인 연구가 필요하다.

\section{요 약}

괴사성 췌장염은 사망률이 높고 괴사된 췌장 부위에 감염 이 동반되어 있을 경우에 패혈증과 다발성 장기 부전이 발생 하여 사망률이 더욱 증가하는 중대한 질환으로 과거에는 수 술적 괴사 제거술이 많이 시행되었지만 최근에는 경피적 배 액술 또는 내시경적 괴사 제거술과 같은 최소 침습 시술이 치료에 널리 이용되고 있다. 저자들은 경피적 배액술과 내시 경적 배액술을 시행하였으나 치료 반응이 없고 임상적으로 악화 경과를 보이는 환자에서 직경이 넓은 식도 금속 스텐트 를 사용하여 경피적 내시경적 괴사 제거술을 시행하여 대장 주변(paracolic gutter)에 있는 막으로 둘러싸인 괴사를 성공 적으로 치료한 사례들을 경험하였고 식도 금속 스텐트를 사 용하여 경피적 내시경적 괴사 제거술이 시행된 증례는 국내 에서 이전에 보고된 바가 없기에 이를 문헌 고찰과 함께 보 고하는 바이다.

국문 색인: 췌장염, 스텐트, 괴사, 내시경 역행 담췌관조영술

\section{Conflicts of Interest}

The authors have no financial conflicts of interest to declare.

The esophageal metal stent was provided free of charge by Taewoong Company (Seoul, Korea).

\section{REFERENCES}

1. van Brunschot S, Fockens P, Bakker OJ, et al. Endoscopic transluminal necrosectomy in necrotising pancreatitis: a systematic review. Surg Endosc 2014;28:1425-1438.

2. van Santvoort HC, Bakker OJ, Bollen TL, et al. Dutch Pancreatitis Study G: A conservative and minimally invasive approach to necrotizing pancreatitis improves outcome. Gastroenterology 2011;141:12541263.

3. Banks PA, Bollen TL, Dervenis $C$, et al. Acute Pancreatitis Classification Working G: classification of acute pancreatitis--2012: revision of the Atlanta classification and definitions by international consensus. Gut 2013;62:102-111.

4. Amano H, Takada T, Isaji $S$, et al. Therapeutic intervention and surgery of acute pancreatitis. J Hepatobiliary Pancreat Sci 2010;17:53-59.

5. van Baal MC, van Santvoort HC, Bollen TL, Bakker OJ, Besselink MG, Gooszen HG, Dutch Pancreatitis Study G. Systematic review of percutaneous catheter drainage as primary treatment for necrotizing pancreatitis. Br J Surg 2011;98:18-27.

6. Beger HG RB, Mayer J, Pralle U. Natural course of acute pancreatitis. World J Surg 1997;21:130-135.

7. Kim TH, Seo DW, Lee SO, Kim SH. Clinical practice guideline for acute pancreatitis: the treatment of local complication of acute pancreatitis and necrotizing pancreatitis. Korean J Pancreas Biliary Tract 2013;18:31-41.

8. Yoon YS, Han HS, Shin SH, et al. Laparoscopic necrosectomy for treating infected necrotizing pancreatitis. J Korean Surg Soc 2008;74:387391.

9. Kahaleh M. Endoscopic necrosectomy for walled-off pancreatic necrosis. Clin Endosc 2012;45:313-315.

10. Attam R, Trikudanathan G, Arain M, et al. Endoscopic transluminal drainage and necrosectomy by using a novel, through-the-scope, fully covered, large-bore esophageal metal stent: preliminary experience in 10 patients. Gastrointest Endosc 2014;80:312-318.

11. Varadarajulu S, Phadnis MA, Christein JD, Wilcox CM. Multiple transluminal gateway technique for EUS-guided drainage of symptomatic walled-off pancreatic necrosis. Gastrointest Endosc 2011;74:74-80.

12. Dhingra R, Srivastava $S$, Behra $S$, et al. Single or multiport percutaneous endoscopic necrosectomy performed with the patient under conscious sedation is a safe and effective treatment for infected pancreatic necrosis (with video). Gastrointest Endosc 2015;81:351-359

13. Kedia P, Parra V, Zerbo S, Sharaiha RZ, Kahaleh M. Cleaning the paracolic gutter: transcutaneous endoscopic necrosectomy through a fully covered metal esophageal stent. Gastrointest Endosc 2015;81:1252.

14. Kwon MH, Kim HS, Kim TH, et al. Percutaneous endoscopic necrosectomy in acute severe pancreatitis with infected necrosis: a case report. Korean J Pancreas Biliary Tract 2013;18:39-44. 